\title{
HUBUNGAN KADAR ANTI MULLERIAN HORMONE (AMH) DENGAN KEBERHASILAN STIMULASI OVARIUM PADA FERTILISASI IN VITRO METODE PROTOKOL PANJANG
}

Ridho Permana, Shofwal Widad, M. Lutfi

\begin{abstract}
Background: Patient with decline oocyte number and quality assumed has lower Anti Mullerian hormone (AMH). AMH concentration which expressed by the granulosa cells of preantral and small antral follicles indirectly determine the ovarian reserve. Therefore, $\mathrm{AMH}$ may be used as a marker of ovarian ageing and associated with ovarian response in in vitro fertilization (IVF).

Objective: To determine the effect of Anti Mullerian Hormone (AMH) on ovarian response in IVF long protocol method.

Method: This research is a retrospective cohort study in Permata Hati Fertility Clinic, IVF program-Dr. Sardjito Hospital, Yogyakarta, Indonesia. Seventy one cycle enrolled in an IVF program conducted from January 2011 through December 2013 at the Permata Hati Fertility Clinic.

Result and Discussion: ROC curve were used to determine cut-off AMH. With cut-off point $2.59 \mathrm{ng} / \mathrm{ml}$, subject divided into two groups (high AMH level: $\geq 2.59 \mathrm{ng} / \mathrm{ml}$ and low AMH level: $<2.59 \mathrm{ng} / \mathrm{ml}$ ). Total dose gonadotropin was significantly different in two groups $(p=0.02)$. High $\mathrm{AMH}$ and low AMH level were significantly associated with ovarian response ( $R R 2,05 ; \mathrm{Cl} 95 \% 1,32-2,20 ; p<0,01$ ). Beside $\mathrm{AMH}$, multivariate analysis shows basal $\mathrm{LH}$ level ( $p=0,04$; OR 7,22; $\mathrm{Cl} 95 \% 1,09-47,87)$ and peritoneal endometriosis ( $p=0,03$; OR 7,80; IK 95\% 1,15-52,81) were significantly influenced ovarian response in IVF. Conclusion: high AMH level influence ovarian response in IVF. Total dose gonadotropin on low AMH levels was greater than high AMH level. In addition to $\mathrm{AMH}$, ovarian response were influenced by basal LH level and peritoneal endometriosis.
\end{abstract}

Keywords: Anti Mullerian hormone (AMH), ovarian response, long protocol stimulation, in vitro fertilization (IVF).

\section{ABSTRAK}

Latar belakang: Pasien dengan penurunan jumlah dan kualitas oosit diduga mempunyai kadar Anti Mullerian Hormone (AMH) lebih rendah. Konsentrasi Anti Mullerian Hormone (AMH) yang dihasilkan folikel ovarium secara tidak langsung menggambarkan cadangan ovarium yang tersisa. Karenanya kadar Anti Mullerian Hormone (AMH) dapat digunakan sebagai prediktor yang akurat dari cadangan ovarium dan respons stimulasi ovarium pada fertilisasi in vitro.

Tujuan: Untuk mengetahui pengaruh kadar Anti Mullerian Hormone (AMH) terhadap keberhasilan stimulasi ovarium pada fertilisasi in vitro pada metode protokol panjang.

Metode: Penelitian ini menggunakan rancangan kohort retrospektif observasional.

Hasil dan Pembahasan: Sebanyak 71 siklus dari 71 pasangan yang menjalani fertilisasi in vitro disertakan dalam penelitian sesuai dengan kriteria inklusi dan eksklusi. Dengan cut off point AMH ditetapkan 2,59 ng/ $\mathrm{ml}$, maka subyek ini dibagi menjadi 2 kelompok yaitu $\geq 2,59 \mathrm{ng} / \mathrm{ml}$ sebagai kelompok $\mathrm{AMH}$ tinggi dan $<2,59$

Bagian Obstetri Ginekologi, Fakultas Kedokteran, Universitas Gadjah Mada Yogyakarta 
$\mathrm{ng} / \mathrm{ml}$ sebagai kelompok AMH rendah. Perbedaan bermakna antara dua kelompok ditemukan pada dosis total gonadotropin $(p=0,02)$.Terdapat perbedaan bermakna respons stimulasi ovarium antara AMH tinggi dan AMH rendah (RR 2,05; IK 95\% 1,32-2,20; $p<0,01)$. Kadar LH basal $(p=0,04 ;$ OR 7,22; IK 95\% 1,09$47,87)$ dan endometriosis peritoneal $(p=0,03$; OR 7,80; IK 95\% 1,15-52,81) juga mempengaruhi respons terhadap stimulasi ovarium.

Kesimpulan : AMH tinggi mempengaruhi respons terhadap stimulasi ovarium. Dosis total gonadotropin pada $\mathrm{AMH}$ rendah dibutuhkan lebih banyak dibandingkan dengan $\mathrm{AMH}$ tinggi. Selain $\mathrm{AMH}$, respons terhadap stimulasi ovarium juga dipengaruhi oleh kadar LH basal, dan endometriosis peritoneal.

Kata kunci : kadar Anti Mullerian hormone (AMH), stimulasi ovarium protokol panjang, fertilisasi in vitro.

\section{PENDAHULUAN}

Fertilisasi in vitro (FIV) merupakan salah satu cara bagi pasangan infertil untuk memperoleh keturunan. Stimulasi ovarium pada program FIV dilakukan untuk mendapatkan sejumlah oosit yang matur dan selanjutnya dilakukan pembuahan in vitro. Oosit matur bisa didapatkan dari siklus alamiah ataupun dengan stimulasi ovarium. Setelah diketahui keberhasilan mendapatkan oosit matur dari siklus alamiah berbeda bermakna dibanding dengan stimulasi ovarium, maka cara ini sudah jarang dilakukan. ${ }^{1}$ Induksi ovulasi bertujuan untuk menciptakan kondisi ovulasi dengan cara memproduksi satu folikel matur yang nantinya akan berovulasi. Stimulasi ovarium diberikan baik pada wanita normal dengan ovulasi teratur ataupun pada wanita dengan gangguan ovulasi, bertujuan untuk mendapatkan folikel yang banyak sehingga akan meningkatkan angka kehamilan. Pada fertilisasi in vitro, prosedur stimulasi ovarium akan menghasilkan lebih dari satu komplek oosit cumulus sehingga setelah dilakukan fertilisasi akan menghasilkan lebih banyak embrio untuk ditransfer dan disimpan beku. ${ }^{2}$

Selama periode kehidupan wanita, terjadi penurunan fungsi reproduksi wanita sehubungan dengan bertambahnya usia. Hal ini disebabkan oleh penurunan cadangan folikel ovarium dan penurunan kualitas oosit. Dibutuhkan suatu marker yang dapat diandalkan untuk menilai cadangan ovarium, sebagai prediktor jangka waktu reproduksi wanita. ${ }^{3}$ Salah satu hormon yang berperan sebagai marker untuk menilai kuantitas dan kualitas cadangan folikel ovarium adalah Anti Mullerian Hormone (AMH). ${ }^{4}$

Anti Mullerian Hormone (AMH) merupakan suatu bentuk transformasi glikoprotein dari transforming growth factor- 8 (TGF- $\beta$ ). Selama ini $\mathrm{AMH}$ lebih dikenal karena perannya dalam diferensiasi seksual laki-laki. AMH diproduksi oleh sel Sertoli dalam testis, menyebabkan regresi duktus Mullerian wanita. Pada wanita, $\mathrm{AMH}$ menunjukkan keterlibatannya dalam fungsi ovarium pasca lahir. AMH dihasilkan oleh sel granulosa pada folikel preantral serta folikel antral kecil dari folikel ovarium. ${ }^{5}$ Level $\mathrm{AMH}$ akan mencapai puncaknya saat fase folikuler akhir. ${ }^{6}$ Pelepasan AMH dari sel granulosa ovarium sebanding dengan jumlah folikel yang berkembang di ovarium, sehingga $\mathrm{AMH}$ juga diperkirakan dapat menjadi marker untuk proses penuaan ovarium karena jumlah folikel yang berkembang pada manusia akan menurun sesuai dengan usia. ${ }^{7}$

Selama AMH diproduksi oleh folikel matur hal ini juga menyiratkan nilai potensial $A M H$ sebagai marker untuk menilai respons ovarium terhadap stimulasi gonadotropin. Konsentrasi 
serum $\mathrm{AMH}$ yang rendah sebelum atau selama terapi FIV berhubungan kuat dengan penurunan jumlah dan kualitas oosit. Hal ini disebabkan karena konsentrasi AMH yang dihasilkan folikel kecil secara tidak langsung menggambarkan cadangan ovarium yang tersisa. ${ }^{8}$ Lebih jauh lagi, kadar serum AMH dapat dilibatkan dalam pemilihan folikel yang sensitif FSH pada early antral stage. ${ }^{9}$

Pemeriksaan cadangan ovarium sangatlah penting dilakukan sebelum FIV. Identifikasi responder yang baik maupun yang buruk terhadap stimulasi ovarium memungkinkan klinisi untuk mengoptimalisasi protokol stimulasi untuk menurunkan tingkat pembatalan siklus dan efek samping, seperti ovarian hyperstimulation syndrome (OHSS). Pembatalan siklus FIV dilakukan bila terdapat poor response yakni terdapat folikel kurang dari empat dengan diameter $>15 \mathrm{~mm}$. AMH diperkirakan dapat menjadi alat prediktor untuk keberhasilan terapi FIV dan maturasi oosit. ${ }^{10}$

Penelitian tentang $\mathrm{AMH}$ belum banyak dilakukan, terutama di Indonesia, sehingga belum banyak orang yang mengetahuinya. Mengingat akan hal tersebut, maka penulis mencoba meneliti hubungan kadar AMH dengan prediksi keberhasilan respons stimulasi ovarium pada proses fertilisasi in vitro.

Tujuan dari penelitian adalah mengetahui hubungan kadar Anti Mullerian Hormone (AMH) terhadap keberhasilan stimulasi ovarium dan membandingkan dosis gonadotropin maupun lama stimulasi ovarium yang diperlukan pada pasien dengan $\mathrm{AMH}$ tinggi dan rendah.

\section{METODE}

Penelitian dilakukan dengan menggunakan rancangan penelitian kohort retrospektif, untuk mencari hubungan seberapa besar pengaruh
$\mathrm{AMH}$ terhadap terjadinya ovulasi pada pasien yang distimulasi dengan gonadotropin. Penelitian dilakukan dengan mengambil data dari rekam medik bulan Januari 2011 sampai Desember 2013 di Instalasi Kesehatan Reproduksi Klinik Permata Hati RSUP Dr. Sardjito Yogyakarta. Subyek penelitian sebanyak 71 siklus dengan kriteria inklusi: wanita usia reproduktif (1845 tahun) yang menjalani stimulasi ovarium menggunakan protokol panjang dan tidak ditemukan kelainan endokrin. Kriteria eksklusi adalah: pernah menjalani operasi pada ovarium; tidak didapatkan data $\mathrm{AMH}$ dalam rekam medik; subyek yang menghentikan program; terpapar kemoterapi dan radiasi.

Variabel bebas penelitian adalah kadar Anti Mullerian Hormon (AMH) dengan cut-off point yang ditentukan kemudian. Sedangkan variabel terikat adalah keberhasilan stimulasi ovarium yang dinilai berdasarkan jumlah oosit yang didapat. Adapun variabel luar meliputi dosis total gonadotropin yang dibutuhkan, lama stimulasi ovarium, umur, Indeks Massa Tubuh (IMT), kadar FSH basal, kadar LH basal, kadar estradiol basal, kadar estradiol puncak, pasien endometriosis peritoneal, pasien dengan Sindroma Ovarium Polikistik (SOPK).

Analisis univariat, bivariat dan multivariat digunakan dalam penelitian ini. Uji chi-square digunakan untuk mengetahui hubungan $\mathrm{AMH}$ dengan keberhasilan stimulasi ovarium. Analisis multivariat dengan regresi logistik digunakan untuk mengetahui variabel yang bermakna terhadap keberhasilan stimulasi ovarium.

\section{HASIL DAN PEMBAHASAN}

Dari total 71 siklus, subyek penelitian dibagi menjadi 2 kelompok berdasarkan kadar Anti Mullerian Hormone (AMH) yaitu kelompok kadar AMH tinggi sebanyak 35 subyek dan kelompok kadar AMH rendah sebanyak 36 subyek. 


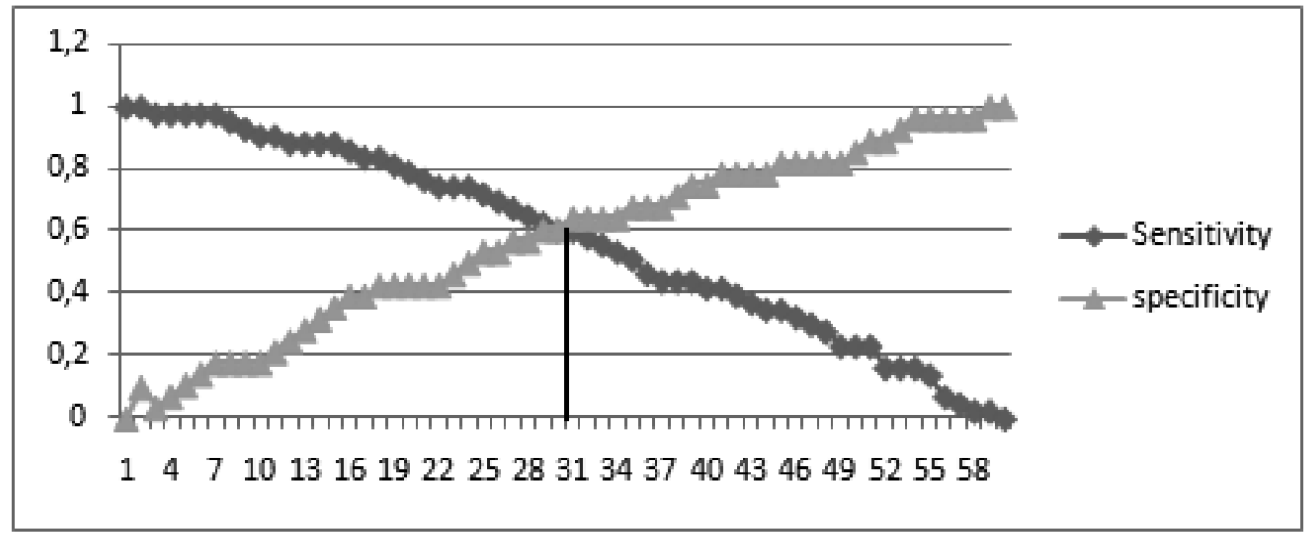

Gambar 1. Penghitungan nilai cut-off menggunakan kurva ROC

Untuk nilai cut-off antara $\mathrm{AMH}$ rendah dan $\mathrm{AMH}$ tinggi, dilakukan pengujian diagnostik menggunakan kurva ROC (Receiver Operating Characteristic) pada program Excel. Daripengujian tersebut didapatkan nilai cut-off sebesar 2,59 ng/ $\mathrm{ml}$. Gambar 1 menunjukkan hasil penghitungan dengan kurva ROC. Selanjutnya untuk pembagian kelompok $\mathrm{AMH}$ tinggi dan rendah digunakan titik potong $2,59 \mathrm{ng} / \mathrm{ml}$.

Dari 71 subyek, didapatkan proporsi usia subyek penelitian <35 tahun sebesar $59,2 \%$ dan $\geq 35$ tahun sebesar $40,8 \%$ dengan usia termuda 24 tahun dan usia tertua 45 tahun. Subyek penelitian yang memiliki IMT $\geq 25 \mathrm{~kg} /$ m2 sebanyak 49,3\%. Lama infertilitas bervariasi dari 1 tahun sampai dengan 25 tahun, dengan reratanya adalah 7 tahun. Sebab infertilitas yang terbanyak adalah endometriosis peritoneal, yaitu sebesar $30,9 \%$. Pembatalan siklus dilakukan pada 2 kasus $(2,28 \%)$, yang disebabkan respons ovarium yang sangat buruk terhadap stimulasi, ditentukan berdasarkan jumlah folikel matang dan munculnya gejala hiperstimulasi ovarium. Jenis protokol stimulasi yang digunakan adalah protokol panjang. Rerata kadar AMH subyek penelitian adalah $2,79 \mathrm{ng} / \mathrm{ml}$ dengan kadar terendah 0,17 $\mathrm{ng} / \mathrm{ml}$ dan kadar tertinggi 9,99 $\mathrm{ng} /$ $\mathrm{ml}$.

Tabel 1. Komparabilitas antara kelompok penelitian program FIV

\begin{tabular}{lccc}
\hline Variabel & $\begin{array}{c}\mathrm{AMH} \geq 2,59 \mathrm{n} \mathrm{g} / \mathrm{ml} \\
(\mathrm{N}=35)\end{array}$ & $\begin{array}{c}\mathrm{AMH}<2,59 \mathrm{ng} / \mathrm{ml} \\
(\mathrm{N}=36)\end{array}$ & Nilai p \\
\hline Usia istri (tahun) & $34 \pm 4,35$ & $35,97 \pm 4,27$ & 0,05 \\
IMT $\left(\mathrm{kg} / \mathrm{m}^{2}\right)$ & $24,76 \pm 3,76$ & $24,39 \pm 5,01$ & 0,72 \\
SOPK & $4(11,4 \%)$ & $5(13,8 \%)$ & 0,75 \\
Endometriosis peritoneal & $12(34,2 \%)$ & $10(27,7 \%)$ & 0,55 \\
FSH basal (mlU/ml) & $6,59 \pm 2,05$ & $6,84 \pm 3,26$ & 0,74 \\
LH basal (mlU/ml) & $3,85(0,84-16,92)$ & $3,40(0,95-6,90)$ & 0,36 \\
E $_{2}$ basal $(\mathrm{pg} / \mathrm{ml})$ & $28,55(3,03-99,46)$ & $22,95(2,98-193,9)$ & 0,23 \\
Durasi pemberian gonadotropin (hari) & $10(6-26)$ & $11(6-22)$ & 0,77 \\
Dosis total gonadotropin (mlU/ml) & $2107 \pm 700,5$ & $2305(1275-5850)$ & $0,02 *$ \\
& $(28$ ampul) & $(31 \mathrm{ampul})$ & \\
\hline
\end{tabular}

Keterangan: *bermakna $(p<0,05)$ 
Dari komparabilitas antara kelompok penelitian program FIV, terdapat perbedaan bermakna pada dosis total gonadotropin $(p=0,02)$. Tidak didapatkan perbedaan yang bermakna dalam hal usia, indeks massa tubuh, adanya SOPK, endometriosis peritoneal, kadar hormon FSH basal, LH basal, estradiol basal, dan durasi pemberian gonadotropin.

Tabel 2. Analisis bivariat variabel bebas dengan variabel terikat

\begin{tabular}{ccccccc}
\hline \multirow{2}{*}{ Variabel } & \multicolumn{2}{c}{ Respons baik } & \multicolumn{2}{c}{ Respons buruk } & \multicolumn{2}{c}{ Statistik } \\
\cline { 2 - 7 } & $\mathrm{n}$ & $\%$ & $\mathrm{n}$ & $\%$ & $\mathrm{RR}$ & $95 \%$ CI \\
\hline $\mathrm{AMH} \geq 2,59 \mathrm{ng} / \mathrm{ml}$ & 28 & 80 & 7 & 20 & \multirow{2}{*}{05} & $1,32-3,20$ \\
$\mathrm{AMH}<2,59 \mathrm{ng} / \mathrm{ml}$ & 14 & 38,9 & 22 & 61,1 & & \\
\hline
\end{tabular}

Keterangan: *bermakna $(p<0,05)$

Dari hasil perhitungan bivariat (tabel 2) variabel bebas dengan variabel terikat, didapatkan bahwa $\mathrm{AMH}$ tinggi berbeda bermakna dibandingkan $\mathrm{AMH}$ rendah dalam hal respons terhadap stimulasi ovarium (RR 2,05; 95\% IK 1,32-3,20; $p<0,01$ ), yang artinya bahwa kadar AMH tinggi akan memiliki peluang sebesar 2,05 kali memberikan respons baik dibandingkan kadar AMH rendah.

Tabel 3. Hasil analisis multivariat variabel bebas dan variabel luar terhadap variabel terikat

\begin{tabular}{lcc}
\hline \multicolumn{1}{c}{ Variabel } & $\begin{array}{c}\text { Adjusted OR } \\
(95 \% \mathrm{Cl})\end{array}$ & $p$ \\
\hline $\begin{array}{l}\text { Kadar LH } \\
\text { basal }\end{array}$ & $7,22(1,09-47,87)$ & 0,04 \\
AMH & $20,76(2,66-161,48)$ & $<0,01$ \\
& $7,80(1,15-52,81)$ & 0,03 \\
\hline
\end{tabular}

Pada hasil analisis multivariat didapatkan hasil bahwa variabel yang mempengaruhi respons stimulasi ovarium adalah kadar $\mathrm{LH}$ basal ( $p=0,04$; OR 7,22; IK 95\% 1,09-47,87), kadar AMH ( $p<0,01$; OR 20,76; IK 95\% 2,66-161,48) dan endometriosis peritoneal $(p=0,03$; OR 7,80 ; IK 95\% 1,15-52,81).

Pada penelitian ini didapatkan bahwa karakteristik pada kedua kelompok penelitian adalah sama. Terdapat perbedaan bermakna dalam hal dosis total gonadotropin antara
$\mathrm{AMH}$ rendah (31 ampul) dengan $\mathrm{AMH}$ tinggi (28 ampul). Hasil ini sesuai dengan penelitian yang menyatakan bahwa pada poor responders (kadar AMH rendah), memerlukan dosis total gonadotropin. $\geq 40$ ampul atau 3000 $\mathrm{mlU} / \mathrm{ml}^{11}$ Suatu Penelitian menjelaskan bahwa kemungkinan peningkatan kebutuhan gonadotropin ini disebabkan karena lebih tingginya distribusi obat dan atau penurunan cadangan ovarium. ${ }^{12}$

$\mathrm{AMH}$ tinggi pada penelitian ini memberikan respons baik yang berbeda bermakna dibandingkan kadar $\mathrm{AMH}$ rendah $(p<0,01)$. Hasil ini sesuai dengan penelitian yang menyebutkan bahwa pada pasien dengan AMH rendah akan menghasilkan oosit yang lebih sedikit dan angka fertilisasi yang rendah dibandingkan dengan AMH tinggi. ${ }^{13}$

Kadar AMH dinilai sangat berguna pada program FIV disebabkan 2 alasan. Pertama, karena dapat menyesuaikan pemberian dosis total gonadotropin pada stimulasi ovarium. Pada saat ini, sebagian besar klinisi FIV menentukan dosis awal gonadotropin pada siklus awal FIV berdasarkan prinsip terhadap usia dan konsentrasi FSH fase folikuler. Jika kadar AMH rendah, para klinisi mempunyai kesempatan untuk meningkatkan dosis awal gonadotropin, sehingga meminimalkan risiko respons buruk 
pada siklus pertama FIV. Kedua, pengukuran AMH sebelum terapi FIV memberi kesempatan pada klinisi untuk menjelaskan kepada pasangan infertil (konseling) tentang harapan akan kesempatan untuk hamil dari satu siklus FIV. ${ }^{15}$

Pengukuran $\mathrm{AMH}$ sebagai penanda cadangan ovarium mempunyai banyak keuntungan dibandingkan penanda yang lain. Kadar $\mathrm{AMH}$ akan mulai turun terlebih dahulu sebelum kadar FSH menjadi abnormal, hal ini meningkatkan sensitifitas tes $A M H$. Kedua, tidak seperti FSH, kadar $\mathrm{AMH}$ tidak mengalami perubahan secara signifikan selama siklus menstruasi, membuat pengukuran cadangan ovarium dimungkinkan setiap hari pada saat pasien datang ke klinik.

Pada saat ini, salah satu halangan penggunaan $\mathrm{AMH}$ untuk memprediksi respons ovarium pada FIV adalah kurangnya standarisasi nilai cut-off $\mathrm{AMH}$, sehingga dihasilkan referensi kadar $\mathrm{AMH}$ yang bervariasi. ${ }^{16}$ Oleh karena itu, disarankan tiap laboratorium FIV agar mengembangkan metodenya masing-masing untuk menentukan nilai referensi normal $\mathrm{AMH}$ dan cut-off untuk menghindari keputusan klinis yang keliru.

Dari hasil analisis multivariat ditemukan bahwa bukan hanya $\mathrm{AMH}$ yang berpengaruh terhadap respons stimulasi ovarium, namun juga kadar LH basal dan endometriosis peritoneal. Penelitian tertentu menyatakan bahwa serum basal LH yang rendah $<4 \mathrm{mIU} / \mathrm{ml}$ dapat memprediksi penurunan respons dari stimulasi ovarium sebagai akibat dari penurunan estradiol puncak dan jumlah folikel preovulatori yang rendah. ${ }^{17}$ Dalam sebuah penelitian disebutkan bahwa respons ovarium buruk lebih tinggi pada endometriosis dibandingkan bukan pada endometriosis. ${ }^{18}$

Kehamilan dan implantasi yang rendah pada endometriosis disebabkan oleh karena buruknya kualitas oosit dan diyakini bahwa buruknya kualitas oosit menyebabkan penurunan rerata fertilisasi. Pada endometriosis ditemukan kualitas oosit, rerata kehamilan dan implantasi yang rendah. ${ }^{14}$

\section{KESIMPULAN DAN SARAN}

Kadar AMH rendah $(<2,59 \mathrm{ng} / \mathrm{ml})$ membutuhkan dosis total gonadotropin yang lebih banyak dibanding kadar AMH tinggi $(\geq 2,59 \mathrm{ng} / \mathrm{ml})$.

Kadar Anti Mullerian Hormone (AMH) tinggi $(\geq 2,59 \mathrm{ng} / \mathrm{ml}$ ), kadar LH basal tinggi ( $\geq 4 \mathrm{mlU} /$ $\mathrm{ml}$ ) dan tidak adanya endometriosis peritoneal akan memberikan respons baik ( $\geq 3$ oosit) pada stimulasi ovarium program fertilisasi in vitro metode protokol panjang.

Untuk kepentingan klinis, pemeriksaan kadar AMH sebelum program fertilisasi in vitro perlu dilakukan sebagai pertimbangan untuk meminimalkan respons buruk stimulasi ovarium pada fertilisasi in vitro.

\section{DAFTAR PUSTAKA}

1. Eldar-Geva T, Calderon I, Maclachlan V, Healy D., 2000, Endocrinology of IVF. In: Trounson AO, Wagdner DK, editors, CRC Press, Florida, 35:65.

2. Macklon NS, Stouffer RL, Giudice LC, Fauser BC., 2006, The science behind 25 years of ovarian stimulation on in vitro fertilization, Endocr Rev, 27(2) : 170-207.

3. La Marca, Sighinolfi G, Radi D, Argento C, Baraldi E, Artenisio A, Stabile G, Volpe A., 2010, Anti Mullerian hormone (AMH) as a predictive marker in assisted reproductive technology (ART), Human Reproduction Update 16(2) : 113-130.

4. te Velde ER, Pearson PI, 2002, The variability of female reproductive aging, Hum Reprod Update 8:141-54.

5. Vigier B, Picard JY, Tran D, 2004, Production of antiMullerian hormone: another homology between Sertoli and granulosa cells, Endocrinology. 114: 1315-1322.

6. Cook CL, Siow Y, Taylor S, Fallat ME., 2000, Serum Mullerian-inhibiting substance concentrations during normal menstrual cycles, Fertility and Sterility 73: 859-861. 
7. Broekmans F, Kwee J, Hendricks D, Mol B, Lambalk C., 2006, A systematic review of tests predicting ovarian reserve and IVF outcome, Human Reproduction Update Advance Access 4 September: 1-34.

8. Wu HH, Wang NM, Cheng ML, Hsieh JN, 2007, A randomized comparison of ovulation induction and hormone profile between the aromatase inhibitor anastrozole and clomiphene citrate in women with infertility, Gynecol Endocrinol 23(2):76-81.

9. Durlinger AL, Gruitjers MJ, Kramer P, 2002, AntiMullerian hormone inhibits initiation of primordial follicle growth in the mouse ovary, Endocrinology 143: 1076-1084.

10. Seifer DB, MacLaughin DT, Christian BP, Feng B, Shelden RM., 2002, Early follicular serum mullerian-inhibiting substance levels are associated with ovarian response during assisted reproductive technology cycles, Fertil Steril 77:468-71.

11. Shaban MM., 2013, Mini-dose long gonadotropinreleasing hormone ( $\mathrm{GnRH}$ ) agonist versus agonist flare stimulation protocol for in vitro fertilization poor responders, Middle East Fertil Steril Soc J.

12. Luke B, Brown MB, Missmer SA, Bukulmez O, Leach R, Stern JE., 2011, The effect of increasing obesity on the response to and outcome of assisted reproductive technology: a national study, Fertil Steril 96(4) : 820-825.

13. Blazar AS, Lambert-Messerlian G, Hackett R., 2011, Use of in-cycle anti-mullerian hormone levels to predict cycle outcome, Am J Obstet Gynecol 205 : 223 e1-5.

14. Speroff L, Fritz MA., 2011, Induction of Ovulation, In: Clinical Gynecology Endocrinology and Infertility 7nd ed, Baltimore New York, Lippincott Williams \& Wilkins:1175-1213.

15. Nelson S.M, Yates R.W, Lyall H, Jamieson M., Traynor I., 2009, Anti-Mullerian hormone-based approach to controlled ovarian stimulation for assisted conception, Hum Reprod 24:867-875.

16. Freour T, Mirallie S, Bach-Ngohou K., 2007, Measurement of serum anti-mullerian hormone by Beckman Coulter ELISA and DSL ELISA: comparison and relevance in assisted reproduction technology (ART), Clinica Chimica Acta, 375 : 162-164.

17. Mukherjee T, Copperman AB, Lapinski R., 2006, An Elevated Day Three Follicle-Stimulating Hormone: Luteinizing Hormone Ratio (FSH:LH) the Presense of Normal Day 3 FSH Predict a Poor Response to Controlled Ovarian Hyperstimulation, Fertil steril 65: 588-593.

18. Hull M.G, Williams J.A, Ray B, Mclaughin E.A, Akande V.A, Ford W.C., 2008, The contribution of suble oocyte or sperm dysfunction affecting fertilization in endometriosis associated or unexplained infertility: a controlled comparison with tubal infertility and use of donor spermatozoa, Human Reproduction, 13:1825-1830. 